\title{
PERANCANGAN SISTEM INFORMASI PENJUALAN HASIL PERTANIAN (petaniunggul.net)
}

\author{
Irwan Tanu Kusnadi ${ }^{1}$, Apip Supiandi ${ }^{2}$, Weli Kusnadi ${ }^{3}$, Rina Riniawati ${ }^{4}$, Rusli Nugraha ${ }^{5}$ \\ 1,2,4,5 Universitas Bina Sarana Informatika \\ irwan.itk@bsi.ac.id, apip.aup@bsi.ac.id, rina.rri@bsi.ac.id, rusli.rng@bsi.ac.id \\ ${ }^{3}$ STMIK Pasim \\ weli.kusnadi.pasim@gmail.com
}

\begin{abstract}
ABSTRAK
Era disrupsi yang dewasa ini melanda tatanan kehidupan manusia menjadi tantangan sekaligus peluang untuk meningkatkan kesejahtraan masyarakat. Indonesia yang merupakan negara yang mempunyai keragaman suku, agama, ras dan antar golongan serta memiliki daerah yang cukup luas sehingga mempunyai keuntungan dalam sektor agraris maupun maritim tapi sayangnya pengelolaan pasca panen yang kurang tertata dengan baik sehingga kesejahtraan hanya dirasakan oleh sebagian orang yang mempunyai modal besar dan mempunyai koneksi dengan para konsumen, sedangkan masyarakat khususnya petani dan nelayan hanya menerima sebagian kecil dari yang harusnya mereka dapatkan, salah satu program pemerintah yaitu Koperasi Unit Desa(KUD) juga hampir di 15 provinsi sudah tidak aktif salah satu faktor yang paling berpengaruh pengelola KUD mengalami kesulitan dalam penjualan dan distribusi hasil panen, padahal dengan adanya KUD maka pendataan, monitoring dan kontrol harga terhadap hasil panen bisa lebih transparan sehingga kesejahtraan masyarakat bisa ditingkatkan, untuk mengatasi permasalahan penjualan dan distribusi hasil panen http://www.petaniunggul.net bisa menjadi solusi nyata yang dapat memotong rantai distribusi penjualan hasil panen menjadi lebih efisien sekaligus sebagai pendataan, monitoring dan kontroling harga yang lebih transparan sehingga kesejahtraan masyarakat khususnya petani bisa lebih ditingkatkan, dan masyarakat sebagai konsumen bisa menikmati pangan yang lebih murah dan berkualitas.
\end{abstract}

Kata kunci: Rancangan sistem, uml, web, koperasi, distribusi pangan,e-commerce, php

\begin{abstract}
The era of disruption that is currently engulfing the fabric of human life is both a challenge and an opportunity to improve the well-being of society. Indonesia is a country that has a diversity of tribes, religions, races and between groups and has a wide enough area so that it has advantages in the agricultural and maritime sectors but unfortunately post-harvest management is not well organized so that prosperity is only felt by some people who have large capital and have connections with consumers, while the community especially farmers and fishermen only receive a small portion of what they should get, one of the government programs namely Village Cooperative Unit (KUD) also in almost 15 provinces is already inactive one of the most influential factors for KUD managers experiencing difficulties in the sale and distribution of crop yields, whereas with the KUD the data collection, monitoring and price control of harvests can be more transparent so that community welfare can be improved, to overcome the problem of crop sales and distribution of http://www.petaniunggul.net bi There is a real solution that can cut the distribution chain of crop sales to be more efficient as well as more transparent data collection, monitoring and price control so that the welfare of the community especially farmers can be improved, and the community as consumers can enjoy cheaper and quality food.
\end{abstract}

Keywords: System design, uml, web, cooperatives, food distribution, e-commerce, php

Diterima Agustus 10, 2019; Revisi Agustus 16 , 2019; Disetujui September 27, 2019 


\section{Pendahuluan}

Pengelolaan, pendataan dan pendistribusian hasil panen mutlak dilakukan agar pemerintah bisa lebih mudah mengontrol harga dan memiliki data yang valid dalam menentukan keputusan, berdasarkan data bulog masalah yang terjadi di lapangan surplus pangan khususnya beras tidak selalu linier dan bulog hanya mampu menyerap 2,14 dari target internal 3,74 ton beras $(57,2 \%)$ sehingga dengan daya serap yang kecil stok pangan menjadi rendah dan memicu terjadinya lonjakan harga dipasar, dan ini merupakan sebuah masalah yang cukup pelik khususnya bagi pemerintah, satu sisi pemerintah harus mampu menstabilkan harga dengan cara menambah suplai pangan dan di sisi lain pemerintah harus berupaya memberikan kesejahtraan bagi para petani dengan mempertahankan harga beli kepada petani dalam negri, permasalahan tersebut terjadi karena estimasi data produksi padi yang selama ini dilakukan Badan Pusat Statistik(BPS) dan kementrian pertanian yang kurang akurat, pendataan produktivitas yang dilakukan dengan aproksimasi sampel lahan petani 2,5×2,5 meter(ubinan) ternyata dilapangan data luas panen tidak diukur secara langsung tapi mengunakan metode perkiraan eye estimation. Sejauh ini sejumlah kajian yang mengkaji data produksi pangan khususnya padi memiliki kesimpulan yang hampir sama yaitu laporan data hasil produksi jauh lebih tinggi dari data sesungguhnya. Pendataan dengan estimasi data bukan solusi yang paling tepat dalam melakukan analisa data dan jauh lebih baik jika pendataan dilakukan dengan estmimasi nyata dimana data produksi yang diambil adalah data produksi yang dicatat di KUD seluruh indonesia sehingga pendataan lebih akurat. Selain dari pendataan yang kurang akurat alur penjualan yang tidak efisien juga menjadi salah satu faktor penyebab terjadinya stabilitas harga yang kurang baik. Masalah yang yang timbul dari uraian diatas dan diangkat untuk penelitian ini adalah: Pendataan hasil panen yang kurang objektif mengakibatkan data simpang siur dan menyebabkan terjadinya pengambilan keputusan yang kurang otimal, distribusi hasil panen yang tidak efisien menyebabkan terjadinya stabilitas harga yang kurang baik, harga yang tidak transparan sehingga sulit bagi pemerintah dalam monitoring dan kontroling harga sehingga petani sebagai produsen yang dirugikan.

Tujuan penelitian dan strategi pengembangan yang diambil dimulai dari pasca panen dengan tujuan: mengaktifkan kembali fungsi KUD sebagai media penampung dan distributor utama hasil pertanian dari petani, sehingga dengan distributor/penjualan yang melewati satu pintu dapat mengurangi rantai alur penjualan yang kurang efisien dan berdampak pada stabilitas harga, mengurangi resiko monopoli dari oknumoknum tidak bertanggung jawab yang menyebabkan kelangkaan barang dan kenaikan harga produk yang tidak normal, memberikan transparansi harga kepada petani dan konsumen sehingga diharapkan petani dapat menerima hasil yang seharusnya petani terima.

\section{Kajian Pustaka}

Kualitas sistem informasi dapat dinilai dari tiga hal yaitu, informasi harus akurat yang berarti informasi harus bebas dari kesalahan dan sesuai dengan kenyataan, kemudian relevan yaitu harus sesuai dengan kebutuhan dan bermanfaat bagi sistem, dan yang ketiga adalah tepat waktu dimana sistem yang berkualitas adalah sistem yang dapat memberikan efisiensi dalam pemrosesan sehingga dapat menyelesaikan perintah secepat mungkin.

Menurut Kusnadi, I.T dkk dalam jurnal: "Rancang Bagun Sistem Informasi persediaan Pakan dan Obat Di PT. CPJF Farm Bantarsari" dalam mencapai suatu tujuan sistem memerlukan proses yang terdiri dari macam-macam tipe proses seperti; proses konsep yang berhubungan dengan rancangan,kemudian proses secara fisik, proses secara prosedur, proses secara sosial dan masih banyak lagi pendekatan proses yang digunakan untuk mencapai suatu tujuan sistem".

Menurut Azhar Susanto dalam bukunya yang berjudul "Sistem Informasi Akuntansi" :

"Sistem adalah kumpulan/group dari sub sistem/bagian/komponen apapun baik phisik ataupun non phisik yang saling berhubungan satu sama lain dan bekerja sama secara harmonis untuk mencapai satu tujuan tertentu".

Menurut Kusnadi, I.T dkk dalam jurnal yang berjudul: "Pengembangan sistem invetori perusahaan menggunakan metoda Usecase Driven" Sekumpulan elemen dan sub sistem yang tergabung dalam sebuah organisasi 
saling berinteraksi dalam mencapai tujuan tertentu baik berupa elemen program basis data maupun hardware dan software sebagai pendukung sebuah sistem. Dalam pengolahan data terdapat tiga blok dasar pengolahan data yang harus terpenuhi yang merupakan siklus pengolahan data yaitu blok inputan data yang berguna sebagai alat input(perangkat tatap muka antara komputer dengan manusia), yang kedua adalah blok pemroses yang berguna untuk pengolahan data yang diinput dan blok terakhir adalah blok output yang berguna sebagai penampil hasil kepada pengguna baik yang ditampilkan pada monitor maupun hasil cetak".

Secara umum program desktop dan program yang berbasis web mempunyai kesamaan dalam sistem perancangan, yang membedakan adalah kebutuhan akan koneksi jaringan internet dalam mendukung kinerja, dimana program desktop hanya berjalan pada satu komputer $\mathrm{pc}$ ataupun dihubungkan dengan jaringan sedangkan program berbasis web pengguna(user) bisa menggunakan program tanpa harus penginstal progra tersebut di komputernya tetapi user harus bisa mengakses server dari program tersebut.

Perancangan sistem informasi bertujuan untuk merancang sebuah sistem, baik pengembangan dari sistem yang sudah ada maupun membangun sistem dari awal sehingga tercipta suatu sistem baru yang handal.

Perancangan sistem dimulai dengan menganalisa kebutuhan sistem, baik berupa kebutuhan fungsional maupun kebutuhan non fungsional sehingga terbentuk alur kerja/rencana kerja untuk memulai merancang sistem, baik yang menggunakan rancangan berbasis objek maupun yang terstruktur,setelah rancangan dibuat kemudian masuk ke tahap implementasi, dimana rancangan sistem yang dibuat diimplentasikan kedalam bahasa pemrograman, setelah program selesai baru diadakan pengecekan untuk program yang dibangun.

\section{Metode Penelitian}

Pelaksanaan penelitian ini menggunakan metode usecase driven dalam pengembangan sistem, dimana usecase digunakan sebagai dasar untuk perancangan diagram sistem yang lainya.metode usecase driven merupakan bagian dari SDLC(System Development Life
Cycle) yaitu teknik dasar pengembangan sistem dalam pelaksanaanya SDLC mempunyai urutan kerja sebagai berikut:

1. Analisa, analisa adalah proses pengamatan dan percarian data yang dibutuhkan oleh sistem baik kebutuhan fungsional maupun kebutuhan non fungsional sistem sehingga sistem bisa dibangun sesuai dengan kebutuhan.

2. Perancangan, tahapan perancangan adalah proses pembuatan blueprint dengan menggunakan tool perancangan sistem baik menggunakan sistem terstruktur maupun yang berbasis objek.

3. Implementasi, yaitu tahap pengembangan atau translasi dari rancangan sistem yang telah dibuat menjadi sebuah program.

Testing, testing adalah tahapan terakhir dalam pembuatan sistem dimana program yang dibuat kemudian dilakukan pengujian.

\section{Hasil dan Pembahasan}

Perancangan sistem pengelolaan dan distribusi pasca panen merupakan sebuah sistem berbasis web commerce yang bertujuan untuk menjembatani Koprasi Unit Desa(KUD) dengan pihak industri yang merupakan konsumen hasil pertanian, dalam pelaksanaannya petani yang menjadi anggota dari koprasi menjual hasil panen kepada koprasi kemudian koprasi mengecek kualitas dari hasil panen dan mengupload di web petaniunggul.net, produk/hasil panen yang di upload KUD dapat dilihat oleh buyer maupun masyarakat sehingga harga produk bisa lebih transparan dan khususnya petani tidak dirugikan karena petani mengetahui harga yang di tampilkan pada website.

Pertaniunggul.net merupakan langkah awal dalam perancangan sistem pengelolaan dan distribusi hasil panen, pengelolaan dan distribusi hasil panen merupakan ujung tombak dalam membangun perekonomian petani khususnya, tanpa adanya pengelolaan dan distribusi yang teratur dan memiliki pangsa pasar yang baik maka bisa dipastikan produk hasil pertanian tidak akan terserap dengan baik sehingga bisa mengakibatkan produk tidak terjual dan KUD mengalami kerugian.

Petaniunggul.net merupakan sebuah alat/media penjualan yang menjembatani KUD dan industri/buyer sehingga hasil panen dapat terdistribusi dan terjual sehingga para petani tidak kesulitan dalam 
menjual hasil panen mereka, dengan adanya pangsa pasar yang baik maka kesejahtraan petani akan meningkat dan pengembangan sistem dapat dilanjutkan kepada sistem pra tanam dan masa tanam termasuk.

Dalam membangun sistem petaniunggul.net dirancang kebutuhan kebutuhan fungsional sistem yang digambarkan memalui usecase diagram seperti pada gambar-gambar dibawah ini:

Usecase Diagram

Usecase diagram menggambarkan kebutuhan fungsional pada program yang akan dibuat sehingga dengan adanya usecase diagram maka proses pengembangan bisa lebih mudah dilaksanakan, usecase diagram yang dirancang disesuaikan dengan kebutuhan dan diberikan hak akses bertingkat sesuai dengan kebutuhan pengguna, secara keseluruhan rancangan program yang akan dibuat digambarkan dalam usecase diagram dibawah ini.

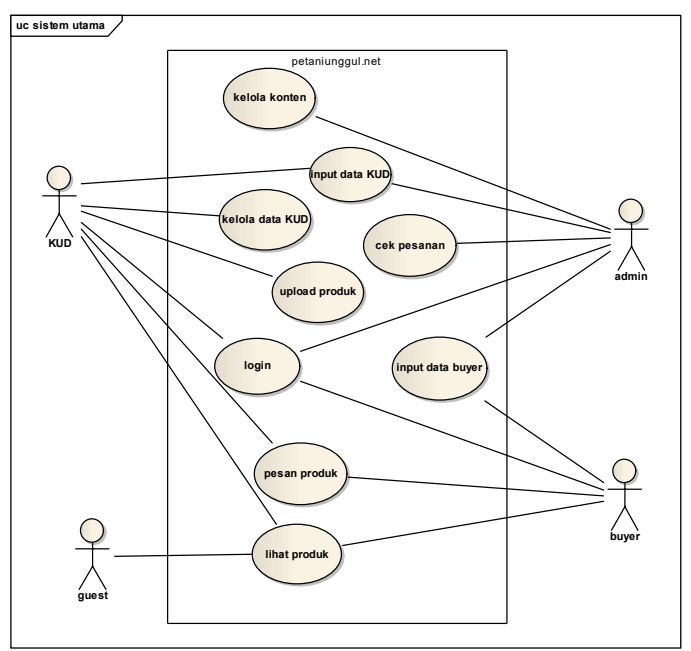

Gambar 1. Usecase diagram petaniunggul.net

Usecase diagram yang menggambarkan kebutuhan dari masing-masing user sehingga dalam tahap implementasi tidak kesulitan dalam memberikan hak akses untuk masing-masing pengguna. Serta memberikan gambaran umum sistem yang akan dibuat, pada diagram usecase diatas kebutuhan fungsional bagi administrator untuk mengelola web sehingga semua tugas dan fungsi dari admin bisa dilihat dari fasilitas yang disediakan pada sistem seperti login, mengelola konten, input data KUD dan data buyer karena web ini bersifat tertutup dalam melakukan transaksi, Cek pemesanan karena untuk alasan keamanan pemesanan baru akan diproses dan di lanjutkan kepada KUD setelah buyer melakukan pembayaran, fasilitas yang diberikan kepada KUD adalah dalam mengelola dan mengakses sistem dan disesuaikan dengan tugas dan fungsi dari pengguna KUD seperti mengelola data KUD, upload produk dan mengelola pesanan, Buyer diberikan fasilitas untuk melakukan login, mengelola data buyer, melihat produk yang di upload oleh KUD dan melakukan pemesanan barang, sedangkan guest/pengunjung diberikan fasilitas untuk bisa melihat konten yang di upload oleh admin dan produk yang di upload oleh KUD. Diagram kedua yang dibuat adalah activity diagram untuk menggambarkan susunan aktivitas yang dilalui pengguna dalam berinteraksi dengan sistem.

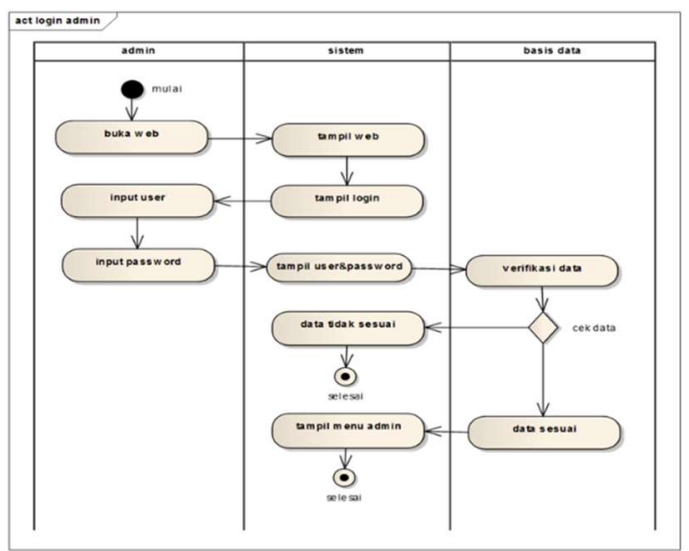

Gambar 2. Activity diagram login admin.

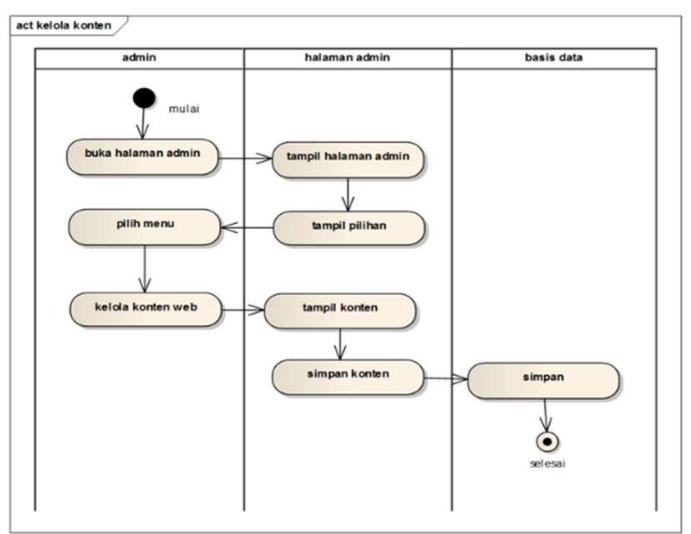

Gambar 3. Activity Diagram Pengelolaan konten.

Gambar 3 diatas menggambarkan aktivitas yang dilakukan oleh untuk melakukan pengelolaan konten baik konten yang 
berupa pengelolaan data user, pengelolaan iklan dan pengelolaan vidio tutorial.

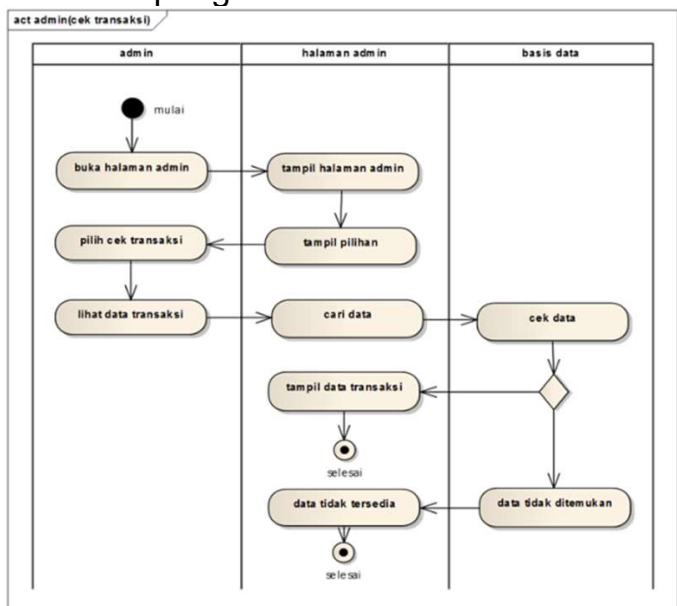

Gambar 4. Activity diagram pengecekan pesanan.

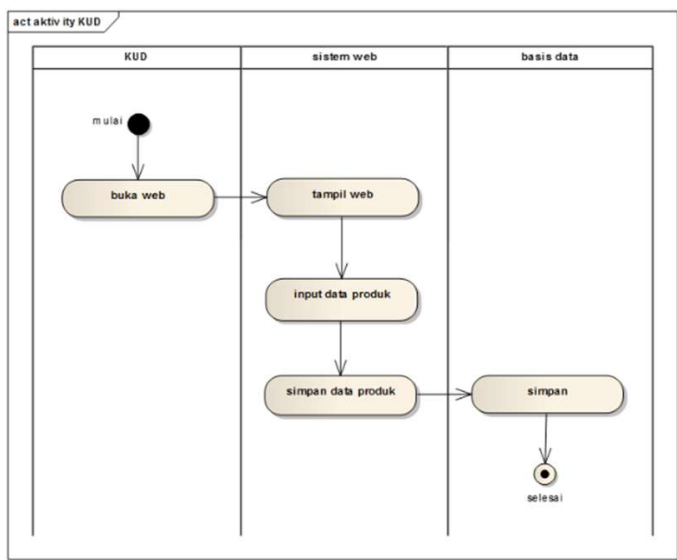

Gambar 5. Activity diagram input produk

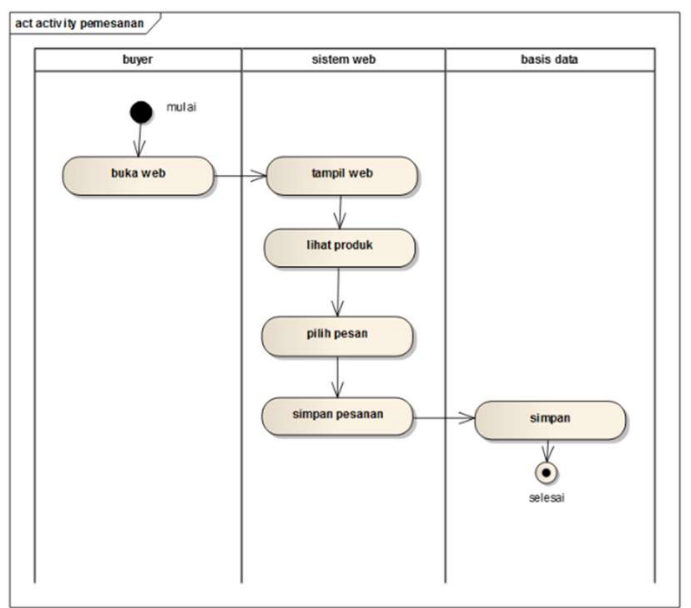

Gambar 6. Activity diagram pemesanan

Setelah menggambarkan activity diagram dilanjutkan dengan menggambarkan deployment diagram yang bertujuan menggabarkan komponen pendukung agar sistem dapat berjalan sesuai dengan kebutuhan.

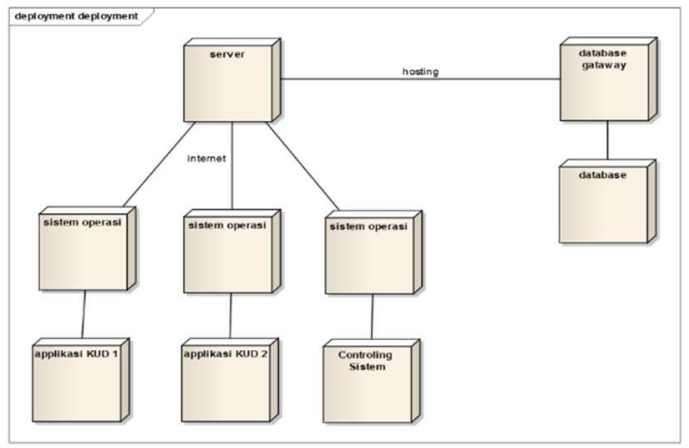

Gambar 7. Deployment diagram

Rancangan Basis data yang dibuat berdasarkan ERD(entity relationship diagram) yang ada dibawah ini, untuk pengelolaan pemesanan dan pembayaran melibatkan admin untuk memberikan kepercayaan kepada buyer dan KUD dalam melakukan transaksi, artinya pemesanan yang diproses adalah pemesanan yang telah diverifikasi oleh admin berdasarkan pembayaran dari buyer, jadi pembayaran masih bersifat manual untuk mengurangi terjadinya kesalahan maupun kecurangan.

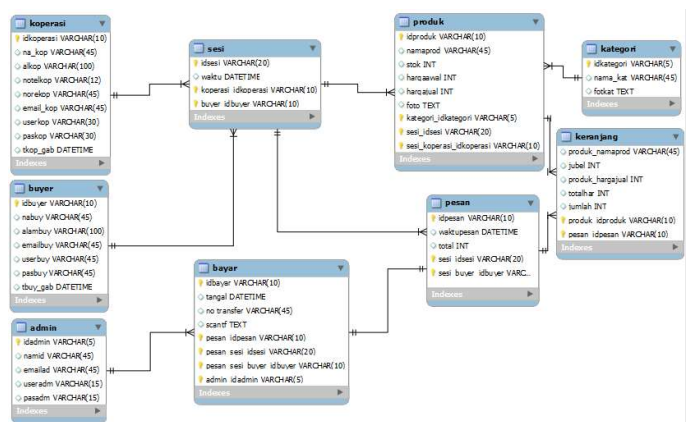

Gambar 8. Entity Relationship Diagram

Implementasi program dari rancangan diatas menggunakan php dengan adobe dreamwaver sebagai softwarenya dan hasil dari tahap implementasi dan pengujian adalah sebagai berikut:

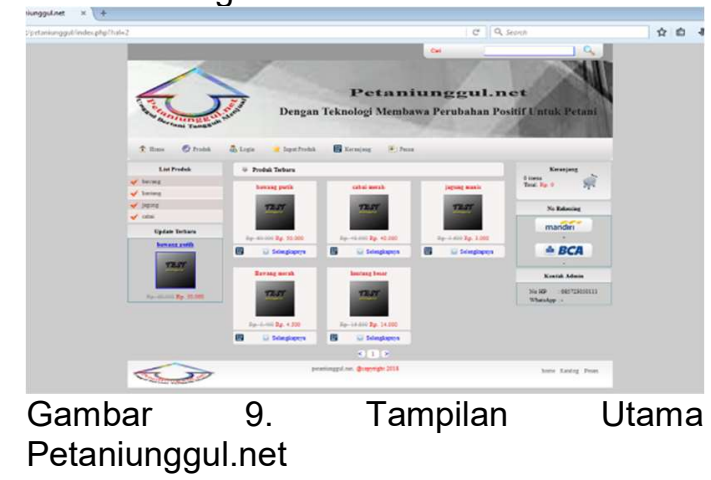



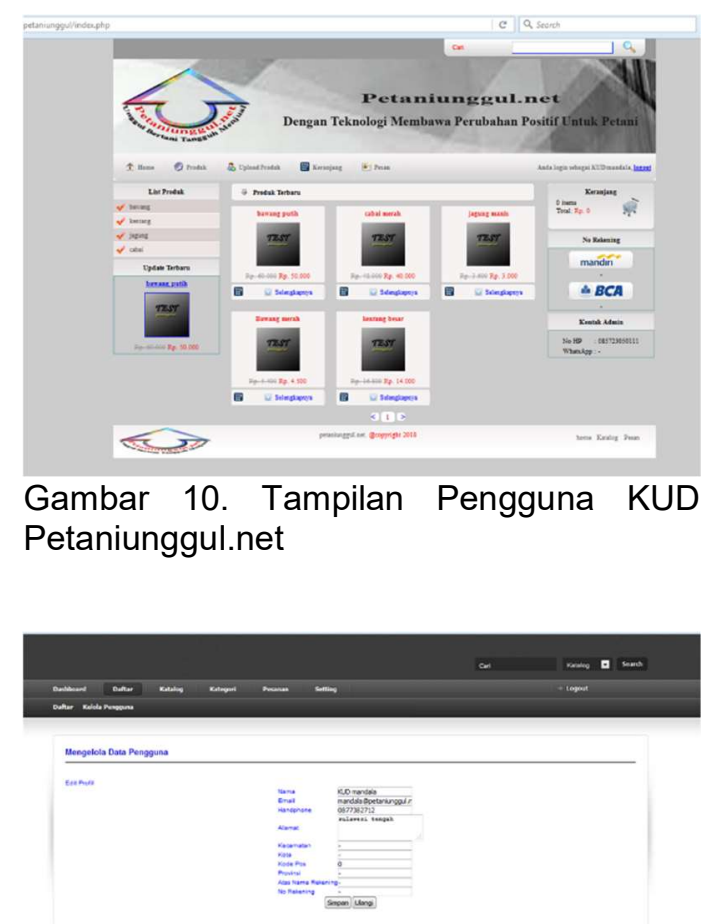

Gambar 11. Tampilan pengelolaan data pengguna.
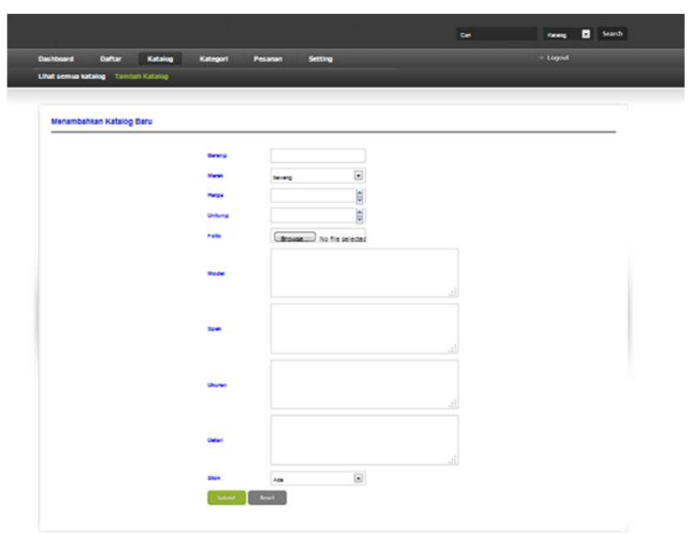

Gambar 12. Tampilan pengelolaan data produk

\section{Kesimpulan}

Strategi pengembangan yang diambil dimulai dari pasca panen dengan tujuan untuk mengaktifkan kembali fungsi KUD sebagai media penampung dan distributor utama hasil pertanian dari petani, sehingga

1. Penjualan yang melewati satu pintu dapat mengurangi rantai alur penjualan yang kurang efisien dan berdampak pada stabilitas harga, serta monitoring atas hasil panen dapat dilihat tidak lagis menggunakan estimasi tapi berdasarkan hasil panen yang masuk ke KUD.

2. Penggunaan petaniunggul.net sebagai jembatan antara KUD dan pihak konsumen dapat Mengurangi resiko monopoli dari oknum-oknum tidak bertanggung jawab yang menyebabkan kelangkaan barang dan kenaikan harga produk yang tidak normal. Karena dengan adanya petaniunggul.net yang memberikan transparansi harga kepada petani dan konsumen sehingga diharapkan petani dapat menerima hasil yang seharusnya petani terima, sehingga diharapkan dapat meningkatkan kesejahtraan para petani.

\section{Daftar Rujukan}

Susanto, A. Sistem Informasi Akuntansi,Struktur-Pengendalian ResikoPengembangan, Edisi Perdana, Lingga Jaya, Bandung, 2013.

Ambler, Scott W,"The element of UML 2.0 Style",Cambridge University Press.

Kusnadi, I.T, Supiandi, A, Kusnadi, W, Riniawati, R., "Rancang Bangun Sistem Informasi Persediaan Pakan dan Obat di PT. CPJF Farm Bantarsari”, Jurnal Informatika, STMIK PASIM Sukabumi, 2018, No.2 Vol.2.

Kusnadi, I.T, Supiandi, A, Kusnadi, W, Riniawati,R., "Pengembangan Sistem Inventori Perusahaan Menggunakan Metode Usecase Driven", Jurnal Teknologi \& Informasi (JATI), UNIKOM Bandung, 2019, No.1 Vol.9.

Pressman, R.,"Software Engineering A Practitioner's Aproach, 7th Edition", MCGrawhill, Newyork, 2010.

Sommerville, I.,"Software Engineering, 8th Edition", Addison-Wesley, 2007.

Http://bulog.co.id/berita/37/6506/10/2/2018/l mpor-Beras-Dan-Validitas-Data---.html 